\title{
From policing to 'social fencing': shifting moral economies of biodiversity conservation in a South Indian Tiger Reserve
}

\author{
Tapoja Chaudhuri ${ }^{1}$ \\ Independent Researcher
}

\section{Introduction}

On a late afternoon in mid-August 2007 at the Vanashree auditorium of the Periyar Tiger Reserve (PTR) in the South Indian state of Kerala, I joined with a group of women from the local village of Kumily. The women were there to receive their monthly training in weaving reed artifacts from dried up Lantana camara - an invasive species harvested from the adjacent forest. The trainings were sponsored by the PTR Forest Department and had been recently introduced as part of several livelihood-generating programs for poor residents of Kumily. As we were taking out training materials from a furniture-filled storage room, my eyes fell upon an old dusty board featuring silhouetted figures of forest guards posed as border patrol force personnel. The forests in India are still protected by forest guards; their boundaries are still firmly drawn. But in a few forest reserves, such posters with highly militaristic symbols are becoming increasingly rare.

This article is an account of the shifting moral economies of biodiversity conservation in India. It illustrates changes in the politics of identity and right-based claims, often working against official neoliberal conservation efforts. It is based on an ethnographic account of community-Forest Department engagement in the PTR, charting the move from policing of forest boundaries that kept local communities at a distance, to 'social fencing' with greater collaboration with communities who engage in voluntary surveillance of forest boundaries in exchange of legitimate access to economic and social benefits. It also describes the emergence of networks of trust and mutual dependence that explain why people from very different socio-economic backgrounds choose to work together when they do, despite legacies of mutual antagonism and conflict.

\section{Background}

In October 2012 PTR was awarded the United Nations India Biodiversity Governance Award by the Government of India and the United Nations Development Programme (UNDP) for the best managed Protected Area in the country (UNDP 2012). Periyar was also designated a 'conservation model' by the Tiger Task Force commissioned by the Government of India in 2005 and has won several accolades in local and national media due to its efforts to improve the local community-Forest Department relationship through various development initiatives (Narain et al. 2005). Such collaborative activities were initiated in 1997 when the World Bank-sponsored India Eco-development Project (IEDP) was introduced in Periyar. The IEDP aimed to reduce dependence of local populations on critical biodiversity habitats by providing the latter with alternative market-based livelihood opportunities (GEF 1998). It is important to note here that the IEDP at Periyar was informed by a variety of ongoing discourses of managing biodiversity in India (and elsewhere) that ranged from militarized vigilance of protected areas (PAs) to decentralizing forest management with greater autonomy for local communities. In this context the project's 'success' is measured both in terms of the tangible impacts on species preservation and long term socioeconomic benefits to the local population. In this article I will provide a nuanced analysis of the multiple factors economic, social, and emotional - that shape the ways in which many local residents in the Kumily village understand the ongoing changes in human-human and human-environment interrelationships.

Local people work with the government and with each other in conservation initiatives, particularly since the passing of legislation in 2005 giving rights to forest dwellers. I present ethnographic vignettes that

\footnotetext{
${ }^{1}$ Dr. Tapoja Chaudhuri. Email: tapoja "at" uw.edu. This work would not have been possible without the support and guidance of many people. I am particularly thankful to the many residents of Kumily who had been extremely generous with their time and very patient with my questions during research from 2005 - 2007. I am also grateful to the officers of the Periyar Tiger Reserve and the Periyar Foundation who were very encouraging and gave me clear access to many Forest Department-sponsored meetings, workshops, educational camps, and trips during my research in Kumily. I would like to thank my Ph.D. research committee: Prof. K. Sivaramakrishnan, Prof. Priti Ramamurthy, Prof. Stevan Harrell, Prof. Craig Jeffrey, and Prof. Daniel Hoffman, for their constant guidance and support. Thanks also to the Wenner-Gren Foundation for Anthropological Research, for awarding me the Wadsworth International Fellowship, and also to the Department of Anthropology at the University of Washington for their Pilot Research Grant (2005). Finally, thank you to Prof. Simon P.J. Batterbury and the anonymous reviewers of the Journal of Political Ecology for your invaluable feedback. Any errors and limitations of this study are my own.
} 
highlight the changing human-environment relationships for two specific social groups from Kumily. First, the village women mentioned at the beginning are part of a loosely formed group called the 'Vasanthasenas' - literally meaning 'guardians of spring'. This group was initially formed by about ten women, mostly from the neighborhoods benefitting from community development initiatives of the IEDP, who wanted to become part of the community-led forest protection initiatives. One of the primarily actions that defines this group is to go on occasional voluntary patrols of the forest in an attempt to look out for acts of illegal poaching or resource collection from the forest. In last few decades many more women have joined the group. However, due to the lack of a formal structure or membership requirements, the actual number of the participants varies over time, depending on the interest levels of participating members. Thus, during my fieldwork in 2007, it was estimated that about ninety women were part of the Vasanthasena group, representing various neighborhoods in Kumily. Currently, according to the official Periyar Tiger Reserve website, this number has reduced to seventy-seven. From time to time, the Forest Department at PTR had also reached out this group to train them in various income-generating initiatives, of which the making of tourist souvenirs from wild Lantana is one.

The second group discussed in this article has a more formal membership and structure. It is comprised of about forty indigenous youths from the Kumily-based tribal communities of the Mannans and the Paliyans who are members of two professional ecotourism eco-development committees (EDCs), viz. the Tribal Tracker's EDC and the Tribal Heritage EDC. Members of these two groups are engaged in conducting various conservation-oriented tours inside the Periyar Tiger Reserve. These two ecotourism programs were specifically formed by the PTR Forest Department at the beginning of the IEDP to create income-generating opportunities for local indigenous youths. Hiking in the forest as part of these eco-tours is seen by the Forest Department authorities to provide extra protection against poaching, particularly against illegal deforestation of valuable sandalwood trees (Santalum album).

\section{Methodology}

This article is based on data gathered from ethnographic research conducted over the summers of 2005 and 2006, as well as on fieldwork conducted in February to December in 2007 in Thiruvanthapuram (the Kerala state capital) and in Kumily. The research was primarily based on participatory observation, and was supplemented by open-ended interviews with a wide variety of individuals. The interviews and all interactions were conducted by myself in both Malayalam (the local language of Kerala) and in English, depending on whom I was talking to. Additionally I conducted archival research, as well as other primary document research, in the state archives of Thiruvanthapuram, and libraries and private collections in New Delhi, Thiruvanthapuram, Peermade (a plantation town near Kumily). In this section, however, I am focusing exclusively on the fieldwork methods that generated data for this article.

I had started out my ethnographic research in Kerala in summer 2005 for two months, primarily in the capital city of Thiruvanthapuram. During this time I met and interviewed a couple of government officers working in the field of tourism, some prominent environmental activists and NGO workers working on issues of sustainable tourism in Kerala, some of the social scientists involved in the designing and the implementation of eco-development programs in Kumily, and some representatives of the private hospitality and tourism industry in the state. For the most part, my open-ended interview questions asked my interviewees their opinions regarding the recent tourism initiatives in the state, with a specific focus on Kerala government's emphasis on 'responsible tourism,' and the interviewees' professional roles in such endeavors. The social scientists and environmental consultants involved in officially evaluating ecodevelopment programs at PTR were asked to share their experience, the kind of research they had undertaken in Kumily, and their opinions regarding the implementation of eco-development program at PTR.

During this first visit I had the opportunity to attend a four day educational and camaraderiebuilding workshop organized by the Forest Department. The workshop provided me with the opportunity to observe and meet the diverse participants of the social world of the Periyar Reserve - including ecodevelopment officers, visiting environmental scientists, forest guards, eco-tourism guides, and 'NGIs' or 'non-governmental individuals' who served as liaison people between the Forest Department and the various local community development micro-schemes. This allowed me to observe the myriad ways in which a wide range of Kumily residents came to be involved in eco-development activities, as well as the actual social processes through which a sense of belongingness developed amongst these participants. I also had the opportunity to observe an eco-development meeting with the indigenous fisher-folks and ecodevelopment officers, negotiating the seasonal quota for fishing in the Lake Periyar - thereby providing me with an opportunity to observe the specific social processes through which resource collectors in Kumily came to negotiate with the Forest Department. This initial visit has also helped me to make first contact with some of the people who became my key informants.

My next, and main, stage of fieldwork began in February 2007. From February to June 2007 I was primarily in the capital city of Thiruvanthapuram conducting archival research on the history of Kumily, as 
well as nature-based recreation in Lake Periyar, at the Kerala State Archives. I had also attended several wildlife-related events in the city that had familiarized me with the some of the main debates regarding nature-based recreation industry in the state. It was during one of these events that I had first met some of the village women from Kumily that lead to my entry into the Vasanthasena group activities that are featured in this article. During this time I also participated in the regional whole-day 'Responsible Tourism' workshop organized by the Kerala Department of Tourism. 'Responsible Tourism' was a new initiative in Kerala that includes notions of environmental, social, and economic responsibilities while promoting tourism in four pilot destinations initially - one of which was Kumily. I would later participate in similar multiple workshops and meetings on 'Responsible Tourism' in Kumily, which showed how actors from both outside and inside the community influence tourism activities with the Forest Department.

The majority of my ethnographic fieldwork comprised participant-observation and ongoing conversations with my key informants had been in Kumily and inside the PTR forest from June 2007 December 2007. I spent most of the days visiting my field informants who worked as tour guides, as minor Forest Department employees (examples: a veterinary lab assistant, receptionist of eco-tourism information center, etc.), and as Periyar Foundation workers. Specifically I spent considerable time observing and talking with about various adivasi eco-guides from the Tribal Tracker's and Tribal Heritage Ecotourism groups, a few other newly minted non-tribal eco-guides and employees of the Periyar Foundation stationed in Kumily. One of my key informants had been a local woman who was a Kumily native, a temporary Forest Department employee, an executive member of EDC, a Vasanthasena member, and the owner of a small souvenir shop in Kumily - a perfect example of the complex and multiple social 'stakes' that many of the Kumily residents embody. I would meet many of these Forest Department employees and/or ecodevelopment participants in their workplaces almost on a daily basis, with occasional visits to their home. This also involved accompanying many of the eco-guides into the forest as they took tourists. Such daily encounters enabled me to study host-guest encounters with visiting tourists, as well as to get an embodied sense of social life in Kumily. My foray into the opinions and worldviews of the Forest Department/Periyar Foundation officials were initially through semi-structured interviews. But I gained most of my valuable insights by spending many hours with these individuals both in 2005 and in 2007. I was particularly able to establish a special connection with the young female Deputy Director (DD) of PTR, and this connection enabled me to have many informal conversations regarding her self-identity as an environmental worker.

While my primary field informants had been those who had been directly involved with ecodevelopment activities, I had also formally interviewed and had long informal conversations with many individuals who had been related to the burgeoning tourism industry in Kumily in their different capacities. These involved interviewing a dozen home-stay owners who were long-time Kumily residents, though economically better-off than the eco-development participants. Other people interviewed (both formally and informally) were the managers of the three star hotels in Kumily that actively promoted the ecotourism programs, eco-development officers, souvenir shop owners - some of whom came from Kashmir in the north for business, a couple of private tour operators, a wide range of tourists - mostly foreigners who availed the eco-tourism services, and a tourism police officer in Kumily. Interviewing these people was helpful in deciphering the emerging networks of social interactions around nature-based recreation in the Periyar forest that were both intensely local while simultaneously spanning the globe. These interviews also provided me the opportunity to understand how people within the socio-geographic universe of the Periyar Reserve interpret the rapid socio-economic changes they have been experiencing, and the different ways in which these individuals chose to negotiate these phenomena.

Additionally, I participated in various training sessions, educational tours, and public meetings organized by the PTR for varying target audiences. Attending public meetings in the context of ecodevelopment activities enabled me to analyze the nature of political rhetoric employed by the forest officers as well as the EDC representatives. I had also accompanied the Tribal Trackers' EDC in a four-day educational tour of five wildlife sanctuaries that allowed me to compare notes with other parks in the state of Kerala. More importantly, it enabled me to observe the specific ways in which the indigenous eco-guides from PTR chose to represent themselves as ecological experts while meeting other indigenous peoples in different parks in the state.

\section{Geographical and social context of the field site}

Periyar Tiger Reserve is situated in the Western Ghats mountain range along the western coast of peninsular India (Figure 1). The core area of the PTR comprising $350 \mathrm{sq} . \mathrm{km}$. is protected as the Periyar National Park (Figure 2). PTR is a natural habitat for several endangered flora and fauna, including charismatic megafauna like the Royal Bengal Tiger (Panthera tigris tigris), the Asian elephant (Elephas maximus), several avifaunal species endemic to the Western Ghats region like the Malabar Grey Hornbill (Tockus griesus) and the Nilgiri Wood Pigeon (Columba elphinstoni), and a large variety of regionally endemic plants. The park features undulating hills covered with tropical evergreen and deciduous vegetation. The bulk of my fieldwork research was done in the village of Kumily that lies adjacent to the forest. Kumily was also the site of most of the community eco-development initiatives undertaken by the 
PTR Forest Department. While technically the Kumily panchayat or the Kumily administrative unit covers about 824 sq. km. (the majority of which is under forest cover) and includes the villages of Periyar and Kumily, I will be referring exclusively to the Kumily 'town' that serves as the entry point for tourism in the tiger reserve. Thekkady (or Thekkadi) is the locality which comprises the main tourism zone of the Periyar Tiger Reserve, as well as the main offices the Periyar Tiger Reserve (East) division.

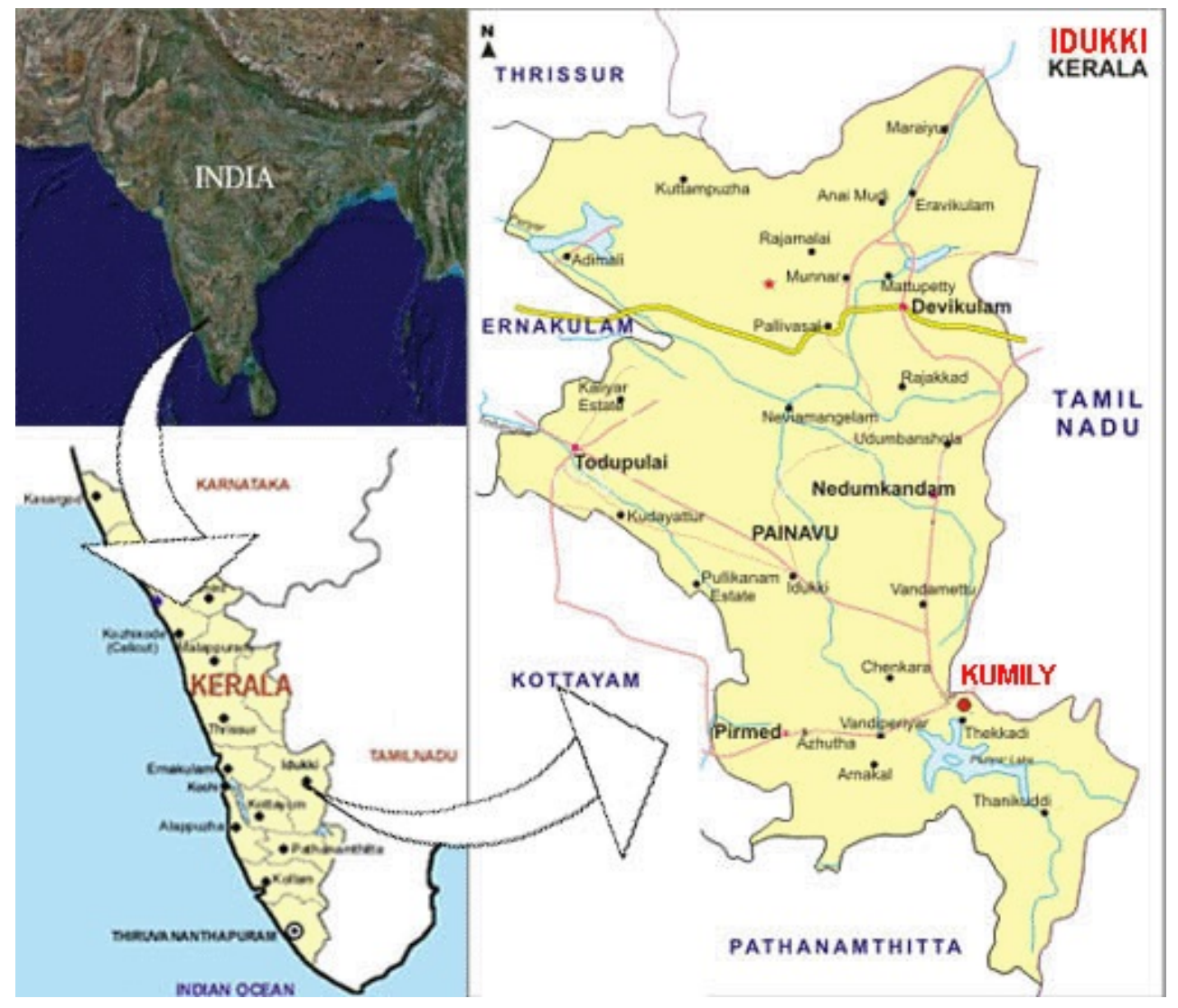

Figure 1: Location of Kumily in Kerala, India. Source: www.vosard.org. Undated.

Periyar Tiger Reserve is one of the most visited wildlife sanctuaries in India with about 300,000 domestic and 25,000 foreign tourists in 2002 (Malik and Veeramani 2002). Thekkady received 170,857 domestic and 27,527 foreign tourists in 2010. But tourism is a relatively new phenomenon (IL\&FS IDC 2012). ${ }^{2}$ It is important to realize that both the names Thekkady and Periyar Tiger Reserve are often used interchangeably in tourism literature and statistical accounts, and it is difficult to decipher how many of these tourists were actually visiting the Park, versus the generic area. While tourism has been popular in India for many decades, it was only during the 1990s that Kerala started appearing prominently on the tourism scene. This was the time that the Indian Ministry of Tourism started its high-budget 'Incredible !ndia' tourism campaign in various international markets. Simultaneously the clever marketing of 'brand Kerala' as the 'God's Own Country' with pristine backwaters, navigable networks of backwaters, and 'exotic culture' started attracting both foreign tourists - mostly from U.K, Germany, and France - as well as an emerging group of Indian young professionals after the economic reforms of the 1990s. The new and relatively expensive ecotourism programs that were introduced by the PTR authorities in late 1990s found a ready market amongst this newly emerging tourist crowd. Ecotourism in Thekkady also hugely benefitted from its strategic location within one of the most popular tourism circuits in Kerala (IL\&FS IDC 2012).

The IEDP was designed to provide livelihood training to the local populations living around critical biodiversity habitats, as a way to win their support for wildlife conservation. It is important to note that India has been experimenting with various forms of participatory forest management schemes since the

${ }^{2}$ It is important to mention here that some of this large tourist crowd are seasonal visitations by pilgrims to the Sabarimala holy shrine, 115 km (76.46 miles) away from Kumily/Thekkady. 
1980s. Joint forest management (JFM) schemes have been implemented in different parts of India, to engage local communities in management of sections of reserve forests. However, the success of the JFM in providing actual community control over forests has been highly variable (Springate and Blaikie 2007, Sundar et al. 2002), and much depends on the ground-level social dynamics. Moreover, as Sarin et al. (2003) note, in many cases the introduction of JFM led to the devolution of community control over local forests and the undermining of customary forest rights. Comparative analysis of various types of community-Forest Department collaborations that range from CFMs (Community Forest Management), JFMs, and Van Panchayats, i.e. village-level forest management committees (Gururani 2000; Sarin 2007; Sharma 2008), prove that while these are all strategies implemented by the Forest Department to defer real democratization of the forestry sector, the actual benefits received by local communities can only be determined on a case-by-case basis (Sarin et al. 2003).

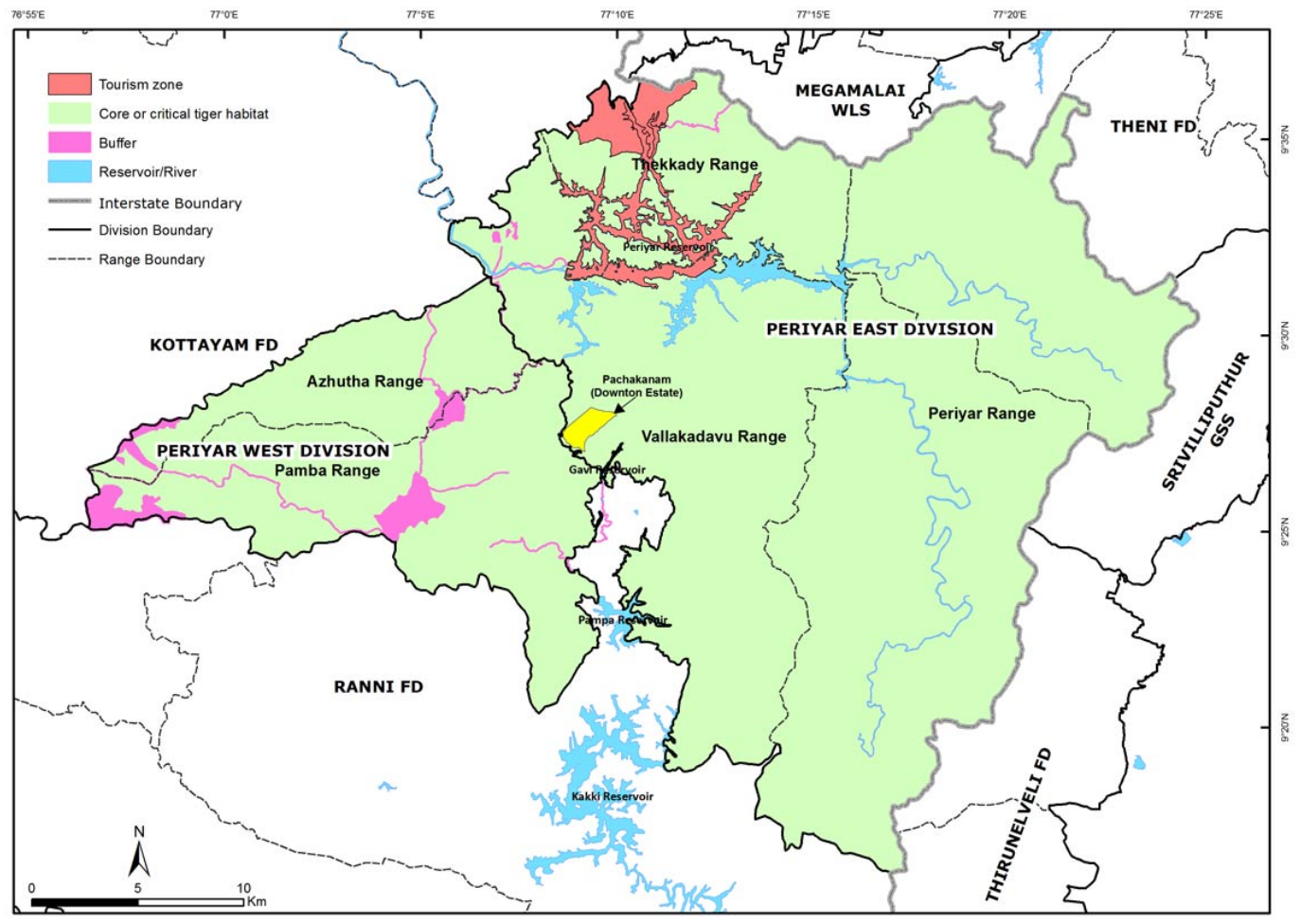

Figure 2: Map of Periyar Tiger Reserve. Source: www.periyartigerreserve.org. Undated.

While it is beyond the scope of the article to analyze the relative merits and demerits of the different participatory forest management schemes in India, suffice to say that the IEDP differs significantly from these earlier schemes. First, unlike the other schemes the IEDP was not impleme]nted in reserved forests, but in national parks. This forecloses any possibility of earning revenue from timber sales. Second, unlike the other schemes the IEDP did not pass on the management to local communities. Decision-making powers remain at the hands of Forest Department authorities. Third, the IEDP relies on the logic of marketbased development as it emphasized the necessity to train local people in 'marketable' skills as a way out of forest dependency and poverty. One can surmise that the IEDP was designed to move local people away from forests, thereby engaging in a different moral economy of human-environment relationship.

It is important to note here that these experiments with different models of forest management that resulted in varying modes of engagement with forest adjacent local communities replicated similar movements in other parts of the world. As Vaccaro et al. (2013) note in their article summarizing the major trends in biodiversity management through protected areas, three different models of protected area management have dominated the conservation discourse worldwide. These three models are:

1) the 'fortress model of conservation' that maintains biodiversity habitats as pristine protected areas that restricts economic activities of the local communities; 
2) the Community Based Natural Resource Management (CBNRM) model that incorporates members of local communities in the management of protected areas; and

3) the neo-liberal model of protected area management that prioritizes self-sufficiency of the protected areas to generate its own revenues and emphasizes public-private partnerships in habitat management in a manner that often marginalizes local communities' participation in management.

Vaccaro et al. (2013) are also quick to note that while each of these paradigms gained importance in a chronological fashion, they might not have been implemented at the same time all over the world, nor does each preclude the co-presence of the others. To this I would add that each of these models had slightly different histories in specific sites. Thus the 'fencing of the forests' (Rangarajan 1999) in India has a colonial legacy, where forests were seen as important sources of valuable timber for the British and hence were fenced off to ensure monopolistic control. Postcolonial endeavors into biodiversity management in India, then, were influenced by this colonial legacy, as well as by the original examples of the 'fortress conservation' model - the national parks of the USA. The simultaneous influences of all three models are also felt in their implementation stages as forest bureaucrats trained under one paradigm are often required to shift between different models of forest management depending on funding sources, thereby making each of these models more of an 'ideal type' (Vaccaro et al. 2013).

The actual implementation of the India Eco-development Programme was influenced by the neoliberal trend in managing biodiversity habitats, that emphasized emerging site-specific micro-plans. Thus, on the one hand the overall functional logic of the IEDP was determined by the global trends captured both in Vaccaro et al.'s account, as well as by the ethnographic account of a NGO-dominated conservationdevelopment scheme in the Crater Mountain Management Area in Papua New Guinea (West 2006). On the other, the presence of site-specific micro-plans enabled the prioritization of grassroots level social realities to influence the designing and implementation of the Programme. At PTR, the Forest Department authorities chose to engage social scientists at different stages of the planning and the implementation of the Eco-development Project. Most of these social scientists highlighted the needs of the poorest sections of Kumily panchayat, with a special focus on local adivasis or indigenous populations. Thus, communitydevelopment programs were first implemented at the tribal hamlets of Mannankudy (Mannan settlement) and Paliyankudy (Paliyan settlement) in Kumily. Concurrently, neighborhood based Eco-development Committees (EDCs) were also set up with representatives from each selected neighborhood outside of these tribal hamlets. The EDCs were to coordinate various community development schemes that ranged from women's micro-credit groups to regulation of the collection of minor forest products. During this time, several new ecotourism programs were also introduced leading to the emergence of professional EDCs, like the Tribal Tracker's EDC. The last group of EDCs was the Users' EDC that catered to specific groups of people who relied on the forest for collecting resources for commercial purposes. One such group was the Fisherfolk's EDC that included adivasi fisher-folks who catch fish from the Periyar lake to later sell in the Kumily market. Allowing such resource collection from a tiger reserve was a highly unusual move on part of the PTR authorities. However, as the Ecotourism Officer at PTR told me in 2005, such moves were allowed since restricting fishing would have led to significant economic hardship for the poor. However, he assured me, such resource collection is not only highly regulated with fixed quotas, but the collection itself was done in an ecologically sustainable manner. The fisher-folks were only allowed to fish Tilapia (Oreochromis mossambicus) - a non-native species.

The IEDP formally ended in PTR in 2001. Soon after a GONGO - a government organized nongovernmental organization - called the Periyar Foundation was founded to carry on with the supervisory functions of the IEDP. Most financial support for IEDP activities now comes from tourism revenue. An amount of Rs.10 (approximately US\$ 0.17) for domestic tourists and Rs.100 (approximately US\$ 1.70) has been added to the ticket for the PTR entry as an eco-development surcharge to the Periyar Foundation. While the Foundation attempted to seek out government grants and private donations from outside sources, it is the eco-development surcharge that formed the core of the operational fund for its activities. Both the PTR Forest Department and the Periyar Foundation are headed by the same person - the Deputy Director of PTR East Division. The conflation of the two organizations is caused by the use of PTR Forest Department authority to sanction many community development initiatives organized by the Periyar Foundation, but also because of the constant sharing of venues and official vehicles.

GONGOs are becoming common in the development sector in India. Sharma (2008) notes that the ambivalent nature of such organizations are used strategically by GONGO workers so that their projects can have the legitimacy of a government organization, while being free to pursue self-directed agendas, free of government bureaucracy. In the context of the Periyar Tiger Reserve, the presence of a GONGO allowed the Forest Department to ask for private donations, engage in a wide variety of educational and entrepreneurial activities for the local community that are normally beyond the scope of the Forest Department, and arrange for impromptu educational outreach programs without going through long bureaucratic dealings. 
While the eco-development programs mostly supported the relatively poor sections of the Kumily community, its impacts touched all sections of Kumily society, including newer residents. While ecotourism programs initially hired young people from the two tribal communities living in Kumily, a range of other economic activities continue to target to the non-tribal community members. Thus, several neighborhood based women's self-help projects that were initiated as part of the eco-development initiatives, continue to coordinate micro-lending practices amongst rural women. From time to time the Forest Department had also tried to introduce several income generating programs for these women like vermiculture (composting), handicrafts making etc. but with little success. Other community development initiatives involve giving educational and infrastructural support to the local community. Interestingly for many local residents the promise of economic opportunities and their aspirations to gain employment in the Forest Department was important. The Forest Department also conducts outreach events for many of the local residents who are not within the purview of the eco-development activities, but indirectly engaged with the burgeoning tourism scene around Periyar Tiger Reserve in their capacities as home-stay owners and tourism service providers.

It is difficult to decipher the exact amount of satisfaction with the Forest Department amongst Kumily residents, particularly since the demographics of the Kumily village near the forest has changed in recent years due to the huge influx of new residents. According to the study conducted by Bhardwaj (2008) - an erstwhile Field Director of Periyar Tiger Reserve and Executive Director of the Periyar Foundation-eco-development activities have resulted in the overall increase of income for the participating community by $24 \%$, specifically benefitting the User group eco-development committees, whose income went up by $70 \%$. At the same time, the study claims that the collection of NWFPs (or nonwood forest produce) that included fodder, grass used for thatching, bamboo etc. fell significantly. Particularly, collection of cinnamon bark and hunting is claimed to have stopped completely after the first ten years of the eco-development activities at PTR.

Anecdotally the nature of support from the local residents can be deciphered from a certain incident that took place during my fieldwork in 2007. A local journalist published an article in a regional newspaper that criticized the PTR eco-development programs for not doing enough for community development. ${ }^{3}$ Almost overnight a group of villagers who were head of their respective neighborhood-based ecodevelopment committees decided to undertake the strenuous sixteen hour round trip to the state capital of Thiruvanthapuram. The purpose of this hurried visit was to meet and appeal to the Minister for Forest - Mr. Binoy Vishwom - to not pay any attention to 'spurious' news articles and jeopardize the future of ecodevelopment activities in PTR. ${ }^{4}$ For some residents of Kumily, however, the relationship with the Forest Department was a little more complicated. Based on my personal interviews, I learned that residents who have been working as private tour guides found that with the introduction of official eco-tourism programs the boundaries of the forest became firmly drawn. While generic eco-development activities might have benefitted their neighborhoods, on a professional level they felt left out of their perceived rightful access to the forest as a zone of employment. Overall, then, the decade-long eco-development programs have contributed to a sense of ownership of the Forest Department by the local community who feel that the former is obliged to provide employment and development opportunities to the Kumily community. And this is a significant shift in the Forest Department - local community relationship in recent decades.

\section{5. 'Social fencing' as a strategy for biodiversity conservation}

One of the key components of the eco-development endeavor in Periyar Tiger Reserve is the concept of 'social fencing,' of which patrols form an important part. In the context of PTR, social fencing was seen as an effective means to protect the park, replacing the necessity for constant surveillance by armed forest guards. For some of the officers engaged in eco-development activities at PTR, this was a new thing - an example of the 'Periyar model of conservation' exemplifying fruitful trust-building between the Forest Department and the local community. The concept of 'social fencing' has long been used in India, particularly in the context of community forestry. Mishra and Sarin (1988) note that it was first popularized in India as early as the mid-1980s when village committees were formed to protect an ecologically fragile grassland in the North Indian state of Haryana. In their account, 'social fencing' essentially meant the emergence of a sense of collective responsibility to protect the grassland by promoting optimal grazing

\footnotetext{
3 Some of the local people alleged that this particular journalist was angry with the Forest Department as his wife had failed to gain permanent employment with them at PTR. Thus, his newspaper articles were a means of revenge. When I met this particular journalist and asked about his motivation for publishing these articles, he said that he is not against the Forest Department, but rather would like the department and the eco-development to actually work for people.

${ }^{4}$ It is here that the distinction between the Forest Department and the Periyar Foundation blurs. Eco-development activities fall within the purview of the Periyar Foundation, and the bulk of the revenue for conducting development activities come from tourism related surcharges, as well as revenue from eco-tourism activities. However, the Periyar Foundation activities are often sanctioned and supervised by Forest Department officials, and hence are connected with the State Department of Environment and Forestry.
} 
activities, and self-policing against over-grazing this landscape. Social fencing, in the current context, also includes surveillance against the destructive influence of 'outsiders', the strong corporate identity of the group members, and institutionalized ways to settle both community rights of access and effective measures to exclude outsiders (Henkemans 2001). The rest of this article gives a glimpse of the social processes through which such strong corporate identity is formed and sustained, as well as the instances where boundaries against perceived 'outsiders' are drawn and maintained.

Authorities at the Periyar Reserve claim that surveillance by villagers has significantly reduced illegal poaching of animals and valuable trees like sandalwood (Santalum album) ${ }^{5}$ Furthermore, the local community has benefitted from the creation of new employment opportunities specifically targeting some of the poorest people. The importance of the PTR case is that elsewhere in India, the IEDP has generally failed to create any lasting benefits for local communities (Baviskar 2003; Down to Earth 2004). Worldwide, there has also been limited success of similar Integrated Conservation and Development Projects (Wells and McShane 2004; Spiteri and Nepalz 2006; West 2006). It is worth mentioning that excessive tourist flow beyond the carrying capacity of the destination, and environmental degradation, were seen as additional threats to biodiversity in PTR. PTR particularly suffered from a huge flow of pilgrims visiting Sabarimala, a Hindu pilgrimage site in the forest. A separate eco-development program was instituted to promote sustainable pilgrimage practices near the site. Additionally, during my fieldwork periods in 2005-2007, PTR was also part of the Government of Kerala-sponsored 'Responsible Tourism' initiative that aimed to reduce environmental stress on Kumily and the Periyar forest. One of the first steps for reducing environmental stress was the banning of plastic bags in Kumily shops in late $2007 .{ }^{6}$ The ecotour guides and the Vasanthasenas are also expected to prevent pollution inside the forest by picking up stray plastic during their walks.

The India Eco-Development Project did not alter the ongoing biodiversity management regime that mandates the maintenance of inviolable core conservation zones. Decision-making powers still remain exclusively in the hands of the Forest Department following a legacy of fenced-in forests dating from the British colonial period (Rangarajan 1999; Sivaramakrishnan 1999). Furthermore, the fact that the newly formed NGO-Periyar Foundation (that is now coordinating eco-development activities) is headed by the Deputy Director of the PTR, illustrates the increasing penetration of the Forest Department in village life. My in-depth conversations with several participants of the eco-development activities in Kumily indicate that many have positive opinions about the greater involvement of the Forest Department in community life, mostly due to the resultant direct and indirect economic opportunities that benefit local residents. More importantly, the Eco-development Project has resulted in improvement of the relationship between the local community and Forest Department. This is particularly important as a recent study based on a survey of attitudes of local communities living around protected areas in India and Nepal show that most people have favorable attitudes towards protected areas, as long as they gain economic benefits from ecotourism and collection of minor forest products (Karnath and Nepal 2012). The relationship with local Forest Department staff, however, is the main cause of difficulty.

Despite the fact that the IEDP was introduced initially as a World Bank and Global Environment Facility funded program, my aim is not to evaluate either the original eco-development program and I cannot conclude that similar sustainable development projects can work anywhere. Rather, I emphasize the role of multiple local and regional factors, some of which might be contradictory to the spirit of an ecodevelopment policy that prioritizes the market as a means to induce biodiversity conservation. These factors play important roles in the interpretation of international environmental policies at the grassroots. Thus, the relative success of community-Forest Department collaboration in Kumily has much to do with the political milieu of Kerala with its strong legacy of grassroots democratization (Isaac and Franke 2002; Li 2010). Issac and Franke (2002) note that while the impetus towards decentralization of governance and augmentation of grassroots democracy came from the $73^{\text {rd }}$ amendment of the Indian Constitution in 1992 that proposed the bolstering of the Panchayati Raj (village-based local administrative units with elected representatives) nationwide. Kerala was particularly successful in implementing it compared to other states of India. Kerala's relative success was facilitated by the already existent vibrant civil society in the state, and the effect of the 'Kerala model of development' with its high rate of adult literacy and legacy of successful land reforms. Kerala's successful decentralization process was also facilitated by the prioritization of financial decentralization before capacity-building of local administrative units, whereas other states chose to focus on capacity-building at local levels as the first step (Isaac 2000).

\footnotetext{
5 The numbers can be found on the Periyar Tiger Reserve website.

${ }^{6}$ From time to time, the Periyar Tiger Reserve was also threatened by the possibility of raising the height of the Periyar dam - an event that would have submerged parts of forest within the tiger reserve. The dam was a bone of contention between the states of Kerala and Tamil Nadu for a long time (c.f. Basheer 2002).

7 Detailed quantitative studies on the economic and perceived social benefits of the IEDP at Kumily have been done by EQUATIONS (2001), Gurukkal (2003), and Mishra et al. (2009).
} 
Lastly, the continuation of the eco-development programs beyond the lifespan of the World Bank project means that we should view it as an independent local program. I found that ongoing ecodevelopment activities at Kumily have resulted in the emergence of new social relationships not only between the local community and the PTR Forest Department, but also between the community members themselves, resulting in new social networks and an emerging moral economy amongst the villagersturned-conservation workers that could not have been anticipated at the onset of the World Bank project (Chaudhuri 2009). I will provide accounts of these new social interactions that mark this emerging community, sometimes referred to as the 'Periyar Family' by some of the Periyar Foundation officers. Here I borrow from phenomenological approaches in social science (Husserl 1977) that analyze the processes through which social actors make sense of their surroundings. My approach towards analyzing what I call the 'social universe' of the Periyar Tiger Reserve is thus motivated by the anthropological tradition of studying meaning-making processes by social actors. Such focus on the individual actors and localized interactions is motivated by a desire to understand the ways in which abstract environmental policies get interpreted, implemented, and manipulated locally.

This study is critical for the current state of wildlife conservation, particularly tiger conservation, in India due to the convergence of several factors. Firstly, in 2005 Sariska Tiger Reserve in Rajasthan was discovered to be completely devoid of tigers, most probably due to poaching. This news created a huge public controversy and led to a justification for severe policing of wildlife habitats by many conservationists. This feeling of an 'emergency period' in wildlife conservation in India was further augmented by the results of a recent tiger census that revealed that there are less than 2,000 wild tigers left in India today. Additionally, a highly debated Scheduled Tribes and Other Traditional Forest Dwellers' (Recognition of Rights) Bill was introduced in 2005, that later became an Act in December 2006. The Act sanctions inalienable rights over four hectares of forest to families belonging to indigenous or other traditional forest dwelling communities (Ramnath 2006). These developments led to intense polarization of civil society debate between what broadly came to be known as the 'people's lobby' and the 'tiger lobby.' In this context the case study urges us to think about possible ways in which the state and the people can work together, even in the context of the continuation of the fortress-model of conservation.

\section{Village women: 'social-fencing' through an ethics of voluntarism}

My first case study showcases a group of women called the Vasanthasenas - literally guardians of spring - who patrol the forest voluntarily (Figure 3). Originally started as a group of ten women, the Vasanthasenas now number about one hundred. The story that is reiterated both by the Forest Department officials, and some of the Vasanthasenas themselves, is that when at the beginning of the IEDP some of the village men got inspired by the various outreach programs of the Forest Department and started engaging in the protection of PTR, about ten village women wanted to replicate the ethics of service showcased by these men. Today the Vasanthasenas are divided into various neighborhood-based EDCs, each taking turns to patrol the forest. In 2006 the Vasanthasenas won the prestigious Amrita Devi Environmental Award given by the Ministry of Environment and Forests for their environmental stewardship.

Since the Vasanthasenas expanded from the original ten women to almost hundred during the time of my research, the motivations of women were varied. There is not much formal structure to the Vasanthasenas, and each neighborhood group patrols the forest on a voluntary basis once in every few months. The women involved in these activities come from similar socio-economic backgrounds, though they vary in their religious orientations. During my fieldwork period in 2007, these neighborhood groups comprised Hindu, Muslim, and Christian women - representative of the very mixed religious composition of Kumily village. Many of these women were essentially housewives. However there were great variations amongst them too. Thus G - one my key informants and friends - was a rare example, having a B.Sc. in Zoology from a local college. She worked as a temporary veterinary laboratory assistant in the Forest Department. On the days that she accompanies her group in the forest every couple of months, she excuses herself from her work to join the patrol. Three other women whom I accompanied while patrolling in the forest were part of a newly introduced eco-tourism hiking program by the Forest Department. Some other women were currently unemployed, but were definitely looking for work. Most of these women were also involved in neighborhood-based women's self-help groups that offered micro-credit. Additionally, some were also involved in various employment-generating schemes that the Forest Department had been experimenting with like vermiculture, pickle-making, making souvenir artifacts like small furniture from reeds collected from the forest.

Despite the inclusion of increasing number of women in the group since its inception, it is the original group of ten women who are often seen as the crux of the program, and often showcased when journalists or wildlife management trainees visit the park. This is also the group that I got acquainted with the very first day I moved to Kumily in June 2007.

My entry into this group had been spontaneous and serendipitous. I first met this group of women in Thiruvanthapuram in a Kerala Department of Environment and Forestry organized event celebrating the 
inauguration of four new stamps by the Indian Postal Service featuring four different wildlife sanctuaries of India, one of which was Periyar Tiger Reserve Kerala. I had met some of the Vasanthasena women during this event as part of the delegation that had travelled from Kumily. About a month later on my first day in Kumily, I was literally picked up on the street by one of these women who recognized me, and took me to visit her home and her neighborhood micro-credit group. During the next few months I would meet some these women multiple times during my daily walks in the village, or would be invited to attend their selfhelp group meetings as well as their children's nature club meetings. It was natural, then, that this was the group of women who invited to join them in their occasional voluntary patrol in the forest. I participated in two such patrols with this particular group. Below is a description of the first of my visits.

On an autumn morning in 2007 I met Vijayamma and nine other middle-aged women outside of the tribal hamlet of Mannankudy. All of them wearing green saris, green raincoats and carrying backpacks - the latter two donated by the Forest Department. Our patrol started from the entrance to the Mannankudy. A few steps inside the village we slipped into the forest through a gap in a wall. This was a part of the forest that was covered by medium-sized woody sandalwood trees. Soon after we entered in clearer section of the forest, and continued our walk along a stream that continues to the Periyar Lake. A little later we passed through a semi-marshy open space and finally ended up on the banks of Lake Periyar opposite the Boat Landing.

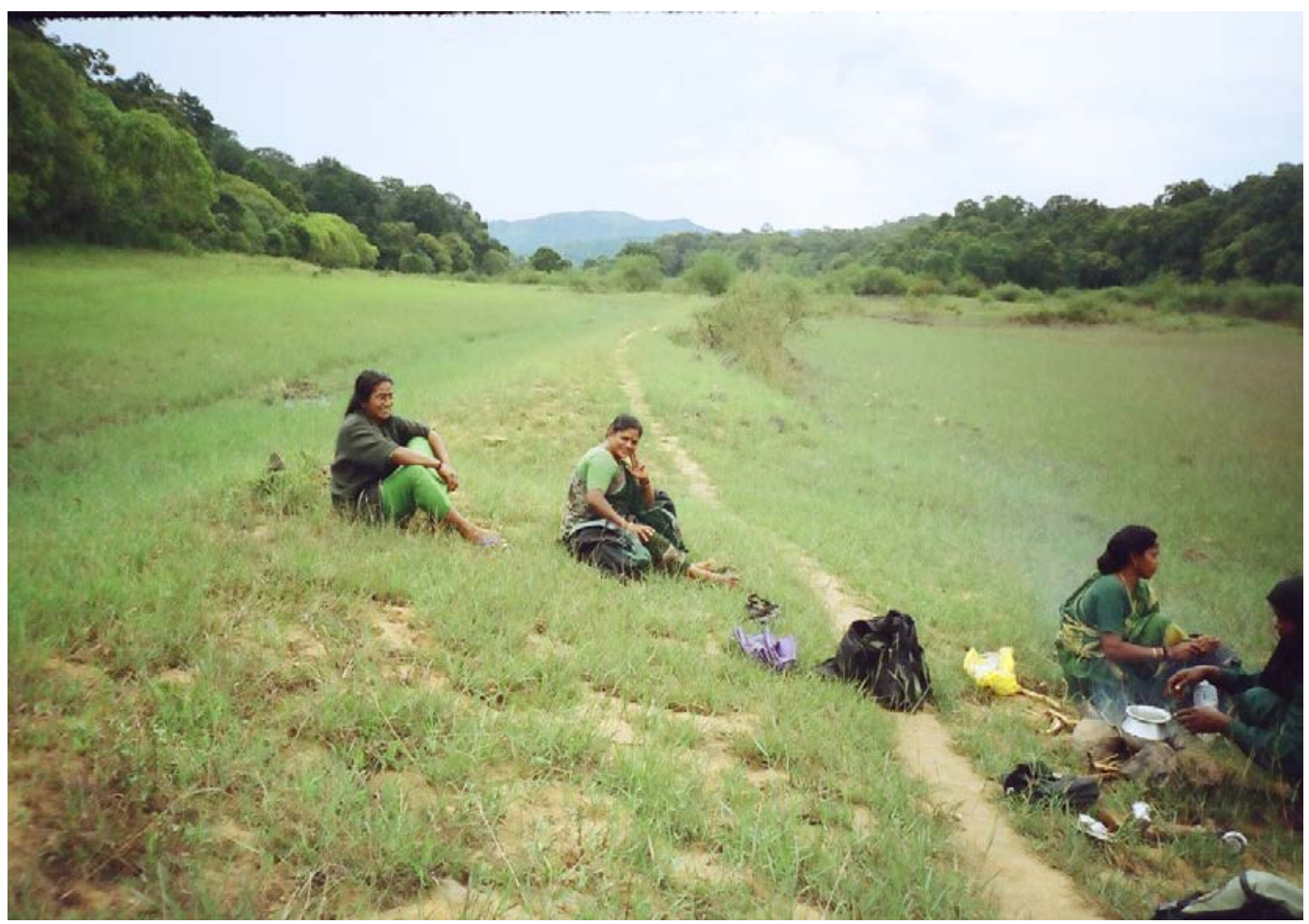

Figure 3: Stopping for some afternoon tea while patrolling the forest with the Vasanthasenas. Source: author, 2007.

Our 'patrol' was interrupted from time to time when we stopped to pluck wild guavas from the trees or sit down on the grass. Some of the women were carrying biscuits (cookies) and fried snacks and soon we started munching on these delicacies even while walking. The general mood was of relaxation and fun, rather than of vigilant patrol. Vijaymma told me that they woke up extra early in the morning to finish domestic chores so that they can come to the forest. One of the women at this point suddenly bent down to pick up a colorful feather from amongst the grass and said 'nalla rasava' (very pretty). She said that she was going to take the feather home [as a decorative object]. When we passed by a group of guava trees everyone promptly got engaged in picking guavas. Some were consumed there and then, the rest were put in their backpacks. One the women turned to tell me that these 'wild' guavas are full of 'guna' (good properties), and are more nutritious than the ones from the market.

During one of our breaks I thought of conducting an impromptu interview with the Vasanthasenas. I turned to the woman sitting next to me and asked her to share her opinions about their relationship with the Forest Department. My interviewee started recounting how during the earlier period they [the women] 
would go to the forest to collect firewood. If caught by forest guards, the firewood would be immediately confiscated and the women had to return home crying. But now that the relationship [with the Forest Department] has improved, they can collect firewood without any fear, and things are better now with the EDCs. It was apparent from her tone that this was a rhetoric she had rendered several times, particularly when meeting visitors at PTR. This is not to say that the sense of relief that village women now felt is not genuine, and indeed accounts of hardships at the hands of forest guards are quite well documented from all over the country (Jeffrey et al. 2003; Krishna 2004). But it is important to recognize that it would not have been equally acceptable for my interviewee to talk about other reasons for her continued engagement with the forest, viz., fun.

As I aborted my attempt to gain access to the 'true story' behind the Vasanthasena's act of volunteerism, I was asked to sing a song. This was a signal for me to stop all the 'serious talks' and just have a nice time. Such notions of the patrol being a time to relax, rather than to be alert, was most evident during the afternoon 'tea time' ritual. While on our way back the women suddenly stopped and started to look around for a suitable spot for building up a makeshift stove. Someone brought matches, another person had brought a jar of milk carefully wrapped in cloth and carried in her backpack, someone else had got tea leaves. Overall the general mood was that of relaxed appreciation of nature and an afternoon off from daily domestic chores.

Why have I provided such detailed description of something as mundane as walking in the forest and making tea? It is clear that the actual patrol can hardly be seen as doing much surveillance work. This is contrary to the much-publicized image of the Vasanthasenas being engaged in 'serious' conservation work. The value of the patrol, then, is to a large extent symbolic. For the women who had started the program and continue to be some of its most enthusiastic participants, it lends a sense of responsibility and dignity, and a sense of ownership over one's local environment. Much is already written about the economic stakes that might motivate people to either collaborate with or to protest against governments, but this study highlights other factors guiding human action. While the Vijaymmas are very adept at portraying themselves as nature stewards motivated by an ethics of biodiversity conservation, their reason for ongoing collaboration is perhaps a much deeper claim on one's local environment. This is particularly true since, paradoxically, with the implementation of the IEDP, such ready access to the forest as a place for relaxation is no longer possible to most Kumily residents. While the local community has benefited economically from the influx of tourism activities around the park, and can also have legitimate access to the forest for resource collection, such access is strictly regimented and monitored - mostly by the villagers themselves. Vijayamma's day out in the forest, then, can be interpreted as a way of re-claiming the moral right to enjoy the forest as part of one's natural landscape - a claim manifested through the embodied practices of picnicking and hanging out.

Apart from my two visits to the forest with Vijayamma's group, I also participated in a third patrol to the forest with another group of Vasanthasenas. One of the members of this group - $\mathrm{G}$ - had been one of my key informants and a friend throughout most of my research period in Kumily. G was a life-long Kumily native, but had been involved with the Forest Department and eco-development activities in her various capacities as the Department's veterinary laboratory assistant, a member of her neighborhood-based eco-development committee, and an enthusiastic participant in many of the Forest Department organized environmental education classes. In 2009 she was an owner of a spice shop in the village catering to the tourist population. I was also familiar with some of a newly-formed ecotourism team that I had been working with. Like with the first group, I was explicitly invited by these women to join them in their forest patrol.

My overall experience of patrolling the forest was similar to the one described above. The route chosen was more or less the same, with similar kinds of activities like picking wild guavas or taking frequent rests. The duration of the trip, however, was shorter, and it seemed that some of the members were in a hurry to return home. This could be a result of two things. First of all, unlike the first group of women, most of the members of this second group were relatively younger and had smaller children to take care of at home. This was a contributing factor for their eagerness to return to home much sooner. Secondly, G mentioned to me that some of the younger Vasanthasena members have joined the program in the hope that perhaps in future they can get a job with the Forest Department. It was their economic aspirations that served as a motivation for doing what is seen as 'conservation work.'

What do these patrols have to do with actual conservation work? One of the greatest conservation threats to India is the possibility of the extinction of wild tigers due to habitat destruction and poaching. It is doubtful that the Vasanthasenas' forest patrols prevent tiger poaching. The patrol routes skirt the peripheries of the forest, and cover areas that are visible from the public areas of the park. The patrol does pass through a sandalwood grove, and sandalwood is a valuable commodity that has been a target species 
for illegal cutting in India. ${ }^{8}$ However, I am not aware of the Vasanthasenas catching intruders in the forest while they were patrolling. For the authorities in the Periyar Tiger Reserve, the value of the Vasanthasenas is symbolic. The forest patrols were part of the overall culture of neighborhood watch-type 'social fencing' activities by the local community in Kumily that was supposed to be vigilant of any 'unauthorized' entry to the forest. The voluntary nature of the patrols was to exemplify the identification of the community members who are most dependent on forests for natural resource collection with the conservation agenda of the Forest Department. This becomes important since the previous antagonistic relationship between the local communities and the Forest Department has improved. Such antagonism, it is important to remember, is often seen as the contributing factor behind the complicity or the active participation of local communities in various poaching and/or deliberate habitat destruction activities the world over (Klooster 2000; Kuhlken 1999; Kull 2002; Robbins et al. 2005).

A glimpse into the two groups of Vasanthasenas showcases the heterogeneity of modalities and motivations among the Kumily residents in their interaction with the forest. It provides us with clues regarding the multiplicity of ways in which local villagers choose to interpret their interaction with the forest and the Forest Department in changing times, highlighting the complex interactions between economic and affective dimensions of social interactions, without necessarily prioritizing either one.

\section{The Adivasis: politics of 'belonging' in changing times}

One of the main discourses around the issue of conservation morality in India, and worldwide, had been the rights of the indigenous peoples (Dahlberg et al. 2010). It is in this context that one must also remember the debates around the Forest Rights Act of 2006 that had divided public discourse. During the height of the debate during 2005 when the Act was proposed, many conservationists saw themselves as 'speaking' for the tigers and wildlife (Dang 2005; Goenka 2005; Jayakrishnan 2005; Sahgal et al. 2005). For the supporters of the Act, on the other hand, it was a question of ensuring dignity and justice for the indigenous populations that had long been exploited by the state and by mainstream society (Narain et al. 2005; Prabhu 2005).

The current account presents us with an alternative narrative that challenges the binary division between a peoples' lobby versus a tiger lobby. It is particularly interesting to note the ways in which the adivasis in Kumily articulate their reactions to the recent changes in the PTR. While the IEDP at the national level did not mention the indigenous populations in India, it is the social scientists hired by the PTR, while drawing up the IEDP site-specific micro-plans, who noted the need to direct development initiatives to the adivasi communities in Kumily due their low socio-economic status. Periyar Tiger Reserve has six different tribal communities living around it. These are Mannans, Paliyans, Malayarayans, Mala Pandarams, Uralis, and Ulladans. The eco-development program, however, chose to work mostly with the Mannans and the Paliyans who lived closest to Kumily, where the bulk of the Eco-development community development program was based. Also, the Mannans and the Paliyans were larger in number than the other tribal communities, and despite their relative socio-economic underdevelopment, they were more integrated with the non-tribal market transactions than the other tribes. A social scientist who was part of the academic team commissioned by the Forest Department to aid in the inception of the IEDP told me it is hard to get an accurate account of some of these tribal communities as they generally like to avoid outsiders.

Both the Mannan and the Paliyan tribal communities have similar histories of living close to the borders of the Kerala and Tamil Nadu, particularly on the forests of the Western Ghats Mountain range in India. While both these communities had been completely forest-dependent in the past, today many engage in trading non-timber based forest resources like honey, timber, fish etc. with the local markets outside their hamlets, or even working in cash crop plantations in the Western Ghat region. In Kumily, it was hard to distinguish between the two communities. Both lived in a neighborhood called Thekkady, adjacent to the forest, in tribal settlements called the Mannankudy (kudy meaning village) and Paliyankudy. Members of both the communities were conversant in Malayalam - the state language of Kerala, while maintaining their own tribal dialects. Of these two tribes, Mannans were more numerous, and had many settlements in other places in the region as well as a tribal king who provides spiritual and cultural guidance. In Kumily they had about 200 households, whereas the Paliyans had almost half that number.

Before the inception of the eco-development initiatives, both the members of these communities were engaged in small-scale agriculture within their settlements. Another main source of income was to sell the fish they would catch in Lake Periyar at the Kumily market. It is interesting to note here that while NFTP collection by local communities in reserved forests and National Parks are often a major bone of contention with Forest Department authorities (Ambinakudige 2011), de facto Forest Department rules

\footnotetext{
${ }^{8}$ One can mention here the case of the Sandalwood mafia figure Veerappan, who was part of a major poaching operation in the South Indian forests of Karnataka, Kerala, and Tamil Nadu between 1992 and 2004. He was also involved in poaching of wild elephants, and had been accused of killing 184 people. He was killed in 2004 by a Tamil Nadu Special Task force that was formed in 1990 specifically for capturing him.
} 
specifically allowed the adivasis at PTR to collect certain NFTPs at a low level. However, research conducted by Robbins et al. (2002) in a North Indian wildlife reserve reveal that while de facto resource collection is often ubiquitous and institutionalized, it is hardly ever completely unregulated or open to perceived 'outsiders.'

One of the main economic difficulties faced by the Mannan community members in particular was their entrapment in endless debt cycles with the moneylenders from Kumily. Many Mannans grow pepper in their small village plots. Before the India Eco-development Project in PTR they often had to take loans from the village moneylenders during lean agricultural periods. As collateral for these loans, they often had to put the harvests from their pepper vines up as collateral, and hence they could not make any profit from the harvest. This would lead the Mannan farmers to take yet another loan from the same moneylenders, and thus enter in a debt cycle. One of the first economic interventions that the Forest Department at PTR did to build up trust with the local Mannan community was to pay these outstanding loans. Currently the Mannan community sells most of their organic pepper and vanilla pods through government-aided auctions. These communities are also allowed to collect firewood for their own use, and harvest elephant grass from the forest that is sometimes used in the village for thatch. Additionally both communities are allowed to continue with their traditional fishing activities within the forest, though fishing now is constrained to Tilapia in Lake Periyar, and according to fixed quotas. Forest Department employment like becoming forest guards has also been a source of income for some. In recent years, eco-tourism activities like 'Tribal Tracking,' 'Green Walk,' and 'Tribal Heritage Tour,' have been significant sources of income for many Mannan and Paliyan youth (Figure 4).

The relative absence of any discourse on the Forest Rights Act in Kumily, or indigenous forest rights in general, has to be understood in this context of economic dependence on the Forest Department. Tribal groups in India often stake their claims as legitimate nature stewards based on their long history of forest-dwelling. Baviskar (1997) notes the recurrence of a 'sons-of-the-soil' rhetoric in many indigenous people's movements over land rights in other parts of India. Such rhetorical strategies are perhaps not surprising in a context whereby long histories of dispossession and marginalization leave indigenous peoples no option but to adopt essentialized political identities, like being true environmental stewards of the world (Krech 1999; Povineli 2002; Ranco 2007; Rupp 2008). I was not surprised, then, to come across similar rhetoric of belongingness used by many members of the adivasi hamlets. However, rather than using such rhetoric to wrest power away from the hands of the government, the Mannans and the Paliyans employ such language of belongingness to argue for greater collaboration with the Forest Department, particularly in the context of ecotourism.

During my casual conversations, as well as during public meetings, I came across a rhetoric emphasizing that 'we tribals' should be allowed to enter the forest, but no-one else from the local community. During an international training session on amphibian conservation that PTR hosted, one Mannan eco-guide said that to ensure species protection it is important that only the tribal people should be allowed to enter the forest. If someone else [from the village community] enters the forest then "all will be gone"' I had come across almost similar response from a young Mannan girl who conducts Tribal Village eco-tours in another context. This girl was selected for a national award for her environmental stewardship sponsored by a prestigious national nature magazine. During her interview she was asked to reflect upon peoples' role in protecting the forest. The girl had noted that while there is normally a symbiotic relationship between humans and the forest, people had started developing a "negative dependence'"' on the forest in recent times. It is only after the Forest Department introduced the eco-development program that twenty/twenty five people (referring only to adivasi eco-guides) are now engaged to protect it. However, if anyone else other than the tribals allowed in the forest, then "everything will be gone."

In another context I accompanied the Tribal Tracker's group, comprising of Mannan and Paliyan young men and the Periyar Foundation education officer, on an educational tour to five wildlife sanctuaries in Kerala. When we visited the Chinnar Wildlife Sanctuary, we met a few adivasi members of the newly minted eco-development project there. Immediately the PTR eco-guides started lecturing the latter about the reasons for the success of PTR. Critiquing the existence of different color schemes for the uniforms worn by Forest Department workers at Chinnar, the PTR eco-guides said that it is essential that everyone working in the same department should wear uniforms of the same color to generate a sense of oneness and shakti (power). They said that the reason that the Eco-development Project was successful in PTR was because the Forest Department first started out building a strong base with the local adivasi communities. Thus, rather than making a gesture of solidarity with the adivasi cause, the PTR adivasis chose to present themselves as proud representatives of the PTR 'success model.' This further illustrates that feelings of pride and convictions about the importance of one's professional role can and do lead to vertical solidarities that can transcend the adivasi/Forest Department/NGO divides that are often highlighted by the people's lobby vs. tiger lobby debates. 


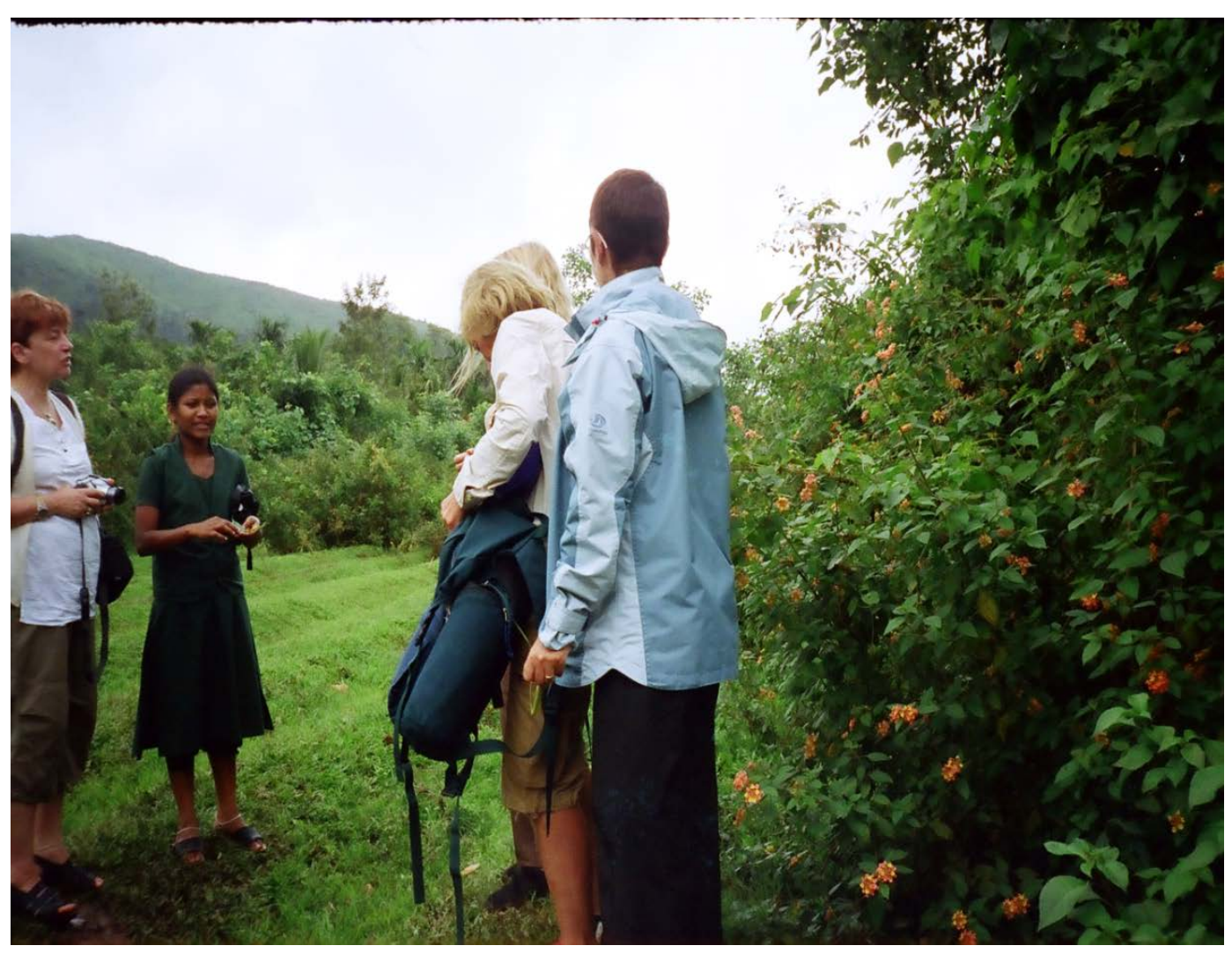

Figure 4: An ethnobotanical Tribal Heritage Tour in progress in Mannankudy. Source: author, 2007.

How can such claims to the forest be understood in the context of local silence about the muchdebated Forest Rights Act in India? I argue that since the tribal communities in Kumily already live outside the forest boundaries, the Forest Rights Act - which sanctions land rights to forest-dwelling communities is not particularly relevant for them. It is more important for these communities to gain exclusive access to the ecotourism market in Kumily. Collaboration with the Forest Department, then, is economically strategic in this context. At the same time, through my ethnographic encounters with different adivasi individuals in Kumily, it was evident that there was widespread belief that the adivasis do have a unique relationship with the forest. In the case of the young girl featured above, it was obvious that her responses were deliberately fashioned to satisfy the urban editor who came to interview her as a potential awardee. And yet, since she had been one of my key informants, I have seen ample evidence of her own belief in the unique role that the adivasis play in sustaining the forest.

The allusion of 'negative dependency' is also to be understood in terms of the moralizing discourse of conservation that is part strategic, and part internalized by many participants of IEDP. Thus my ethnographic experience with the tribal eco-guides leads me to view such discursive instances as something more than a mere example of ideological hegemony, or a pure act of economic strategization. It would be too simplistic to presume that such discursive practices described above were merely paying lip service to conservation ideology in order to receive economic gains in a highly competitive market. It would also be unrealistic to presume that all members of the tribal communities validate the centrality of the Forest Department as the key environmental steward for PTR. The Forest Department authorities, for example, would often direct me to the 'knowledgeable' members of the community, meaning those EDC members who were the most articulate supporters of the newly introduced mechanisms like 'social fencing.' But regardless of the question of intentionality, it is important to note that the correct answer was at a least verbal support of the Forest Department in the protection of the forest. The tribal-state relationship in PTR is more nuanced and multi-layered than can be captured in globalized debates regarding wildlife conservation versus indigenous/local community rights. 


\section{Discussion and conclusion}

In this article I have provided a few ethnographic case studies that help us to understand the ways in which people experience shifting norms of biodiversity conservation in a specific forest in India. Such shifts are neither radical, nor total, in nature. And yet, they can bring about very important changes in the daily lives of local people. These are what Rajan and Duncan (2013) call 'middle level changes,' involving local level negotiations and innovations that might not be revolutionary, but nevertheless can have significant positive impacts in the lives of the participants. As they note, "...these struggles, which in themselves might not make for a fundamental or structural change, do enable a slightly more livable world, contributing pieces toward a great transformation." (Rajan and Duncan 2013: 75).

Moreover, such changes may be understood not just in terms of economic benefits, but also in terms of fundamental shifts in the nature of relationships between different social actors. My ethnographic case studies of the Vasanthasenas and the adivasi eco-guides can easily be interpreted as analyses of different stake-holders in PTR who stand to gain economically by collaborating with the Forest Department. Indeed, the 'success' of PTR can be, and often is, explained in terms of the fruitful reconciliation between the different rational needs of resource users and conservationists (Mishra et al. 2009). And yet, a closer look at the world of Periyar reveals that the people involved in day-to-day interactions with each other make sense of their mutual obligations to protect the forest through a complex language of friendship, economic dependence on the forest as a zone of international tourism, and as a fragile eco-system with many apurvamaya (amazing) and ivere matra undu ('it is found here'; endemic) flora and fauna.

Further, ethical questions are raised in the PTR particularly since people from very different social backgrounds and life chances depend on each other for their daily lives. It is also true that much of this interdependence is caused by an economic reliance on the forest as the source of livelihood - either as a unit of administration, or as a site of tourism activities. But the way in which such interdependence and interaction is expressed is in terms of the moral component of the greater duty towards one's natural heritage (Chaudhuri 2012). While everyday life is not always paralyzed by ethical dilemmas (Goffman 1959) and much of social life is conducted as part of routine activities, the deliberate allusions to duties of 'the Periyar Family' and the need to curb 'negative dependence' point to the central role that such questions of ethics play in making conservation work meaningful for the people engaged in it.

The question of ethical discourse becomes important in understanding the politics of identity and right-based claims in India. The case studies of the Vasanthasenas and the adivasis illustrate the complex ways in which individuals might have to negotiate between different value systems in a constantly changing world. To say that the residents of Kumily incorporated, at least to some extent, the value of preserving nature is not to deny the role of power relationships vis-à-vis the Forest Department. But to presume that local peoples are co-opted by state ideology is to misunderstand the heterogeneous nature of the state as an institution, and to deny the existence of human agency.

The PTR story may also be understood in the context of increasing control over land by the state and by private capital, often in collusion with each other, in India and elsewhere in the developing world. Thus, even when India has just implemented its Forest Rights Act, it has at the same time declared the creation of more tiger habitats. The Memoranda of Understanding signed between the different state governments in India and corporations for mineral resources in ecologically fragile forests speaks of a land-grabbing phenomenon (Bidwai 2006; Sahu 2008; Ramachandraiah and Srinivasan 2011). Land grabs are increasingly common on a global scale (Fairhead et al. 2012; Li 2010). In this context it is important to question if the Forest Department at PTR is allowing minor concessions while they still maintain their hold on the premium forest reserve. At the same time it is important to realize that the case of the PTR forest reserve is unique, as its core zone is a national park and hence cannot be used for commercial purposes. Secondly, from the global commons literature (Feeny et al 1990; Ostrom 1990), it is evident that the customary commons never meant a free-for-all, but rather engaged with specific communities as responsible stewards - somewhat like the model followed at PTR while still maintaining the fortress model of conservation.

One of the key questions, then, remains to what extent can we reconcile the moral meta-narratives of human-environment relationships that shape environmental policies and rights-based social movements, and the idiosyncratic social universes marked by fluid codes of ethics and unique moral economies? This question becomes particularly pertinent in the context of neoliberalism where the homogenizing forces of globalization are accompanied, paradoxically, by emphasis on decentralization and local entrepreneurship, leading to specific context-based realities; even in the sphere of biodiversity conservation. The PTR case illustrates that even when the original premise of the IEDP prioritized market-based logic to incentivize local communities to support fortress conservation, the ground-level implementation of IEDP at PTR was far from a simple illustration of neoliberal environmentality (Fletcher 2010). In conclusion, the current analysis suggests the necessity to bolster local democratic institutions and access to information to ensure social justice, even when radical change is not possible. 


\section{References}

Ambinakudige, S. 2011. National Parks, coffee, and NFTPs: the livelihood capabilities of Adivasis in Kodagu, India. Journal of Political Ecology 18: 1 - 10.

Anathakrishnan, G. 2010. Women walk on the wild side. Times of India. January 2 [accessed on June 12, 2013]. http://articles.timesofindia.indiatimes.com/2010-01-02/india/28143776_1_vasanta-senavasanta-sena-periyar-tiger-reserve

Baviskar, A. 1997. Tribal politics and discourses of environmentalism. Contributions to Indian Sociology 31(2): $195-223$.

Baviskar, A. 2003. Uneasy allies: tribal politics and discourses of Indian environmentalism. In P.R. Greennough and A. L. Tsing (eds.) Nature in the global south: environmental projects in South and South East Asia. Durham NC: Duke University Press.

Basheer, K.P.M. 2002. Raising of Periyar dam level: threat to biodiversity. The Hindu January 8. [accessed June 12, 2013]. http://hindu.com/2002/01/08/stories/2002010801140600.htm

Bhardwaj, A.K. 2008. Assessment of eco-development initiatives in Periyar Tiger Reserve, Kerala. Dissertation. Dehra Dun: Wildlife Institute of India.

Bidwai, P. 2006. The great land grab. Frontline September 9. [accessed on August 31, 2012] http://www.tni.org/article/great-land-grab.

Chaudhuri, T. 2009. Social universe of a Protected Area: community-based ecotourism in Periyar Tiger Reserve. PhD Dissertation, Department of Anthropology. Seattle: University of Washington.

Chaudhuri, T. 2012. Learning to protect: environmental education in a South Indian Tiger Reserve. In H. Kopnina (ed.) Anthropology of environmental education. New York: Nova Science Publishers.

Dahlberg, A., R. Rohde and K. Sandell. 2010. National parks and environmental justice: comparing access rights and ideological legacies in three countries. Conservation and Society 8(3): 209-224.

Dang, H. 2005. The end of conservation. Seminar \#552.

Down to Earth. 2004. Officially bankrupt: one stove, one post. [accessed on August 20, 2011] http://www.indiaenvironmentportal.org.in/node/546.

EQUATIONS. 2001. India Eco Development Project. Periyar Tiger Reserve: visitor management and participatory ecotourism strategy for Periyar Tiger Reserve and surrounds. Bangalore: EQUATIONS.

Fairhead, J, M. Leach, and I. Scoones. 2012. Green grabbing: a new appropriation of nature? Journal of Peasant Studies 39(2): 237-261.

Fletcher, R. 2010. Neoliberal environmentality: towards a poststructuralist political ecology of the conservation debate. Conservation and Society 8(3): 171-181.

Franke, R. W and T. M. T. Isaac. 2002. Local democracy and development: the Kerala people's campaign for decentralized planning. Lanham: Rowman and Littlefield Publishers. .

GEF Project Report. India EcoDevelopment Project (Cr. No. 2916-IN; GEF TFG No. TFO28479-IN). 1998. Management response to Inspection Panel. [accessed on August 8, 2013]

Goffman, E. 1959. The presentation of self in everyday life. New York: Anchor.

Goenka, D. 2005. A non-solution. Seminar \#552.

Gurukkal, R. 2003. The Eco Development Project and the socio-economics of the fringe area of the Periyar Tiger Reserve: a concurrent study. Final Report Submitted to the Co-ordinator, KRPLLD.

Gururani, S. 2000. Regimes of control, strategies of access: politics of forest use in the Uttarakhand Himalayas, India. In A. Agrawal and K. Sivaramakrishnan (eds.) Agrarian environments: resources, representations, and rule in India. Durham and London: Duke University Press. Pp 170 - 190.

Henkemans, A.B. 2001. 'Tranquilidad' and hardship in the forest: livelihood and perceptions of camba forest dwellers in northern Bolivian Amazon. PhD Dissertation. PROMAB Scientific Series 4. Utrecht: University of Utrecht.

Husserl, E. 1977. Cartesian mediations: an introduction to phenomenology. Dordecht: Kluwer Academic Publishers.

IL\&FS IDC (Infrastructure Development Corporation Ltd.). 2012. Identification of tourism circuits in India: interim report Kerala. Submitted to Ministry of Tourism, Government of India. New Delhi.

Isaac, T.T.M. 2000. Campaign for democratic decentralization in Kerala: an assessment from the perspective of empowered deliberative democracy. Thiruvanthapuram: Center for Development Studies and Kerala State Planning Board.

Isaac, T.T.M. and R.W. Franke. 2002. Local democracy and development: the Kerala people's campaign for decentralized planning. Lanham: Rowman and Littlefield.

Jayakrishnan, P.V. 2005. Is there a need for this Bill? Seminar \#552. 
Jeffery, R. and N. Sundar, with A. Mishra, N. Peter and P.J. Tharakan. 2003. A move from minor to major: competing discourses of nontimber forest products in India. In P. Greenough and A.L. Tsing (eds.) Nature in the global South: environmental projects in South and Southeast Asia. Durham: Duke University Press. Pp 79-102.

Karnath, K.K. and S.K. Nepal. 2012. Local residents perception of benefits and losses from protected areas in India and Nepal. Environmental Management 49(2): 372-386.

Klooster, D. 2000. Community forestry and tree theft in Mexico: resistance or complicity in conservation? Development and Change 31(1): 281 - 305.

Kothari, A. and N. Pathak. 2004. Periyar Tiger Reserve: of people and participation. The Hindu: Survey of the Environment. Chennai: Hindu Group of Publishers.

Krech, S. 1999. The ecological Indian: myth and history. New York: W.W. Norton \& Co.

Krishna, S. 2004. Gender, tribe and political participation: control of natural resources in North-eastern India. In S. Krishna (ed.) Livelihood and gender: equity in community resource management. Thousand Oaks: Sage Publications. Pp. 375-395.

Kuhlken, R. 1999. Settin' the woods on fire: rural incendiarism as protest. Geographical Review 89(3): 343 $-363$.

Kull, C.A. 2002. Madagascar aflame: landscape burning as peasant protest, resistance, or resource management tool? Political Geography 21(7): 927 - 953.

Li, T. M. 2010. To make live or let die? Rural dispossession and the protection of surplus populations. Antipode 41(1): 66 - 93.

Mallik, A and Veeramani, A. 2002. Periyar Tiger Reserve: ecotourism initiatives involving local communities. Paper presented in VIth training workshop on 'Ecotourism Project Development and Marketing' organised by Wildlife Institute of India, Dehra Dun at Spice Village, Thekkady, Kerala, India.

Mazoomdar, J. 2005. If Sariska wasn't enough. Sanctuary Asia. June.

Mishra, B.K., R. Badola and A.K. Bhardwaj. 2009. Social issues and concerns in biodiversity conservation: experiences of wildlife protected areas in India. Tropical Ecology 50(1): 147 - 161.

Mishra, P.R. and M. Sarin. 1988. Social security through social fencing, Sukhomajri and Nada, North India. In Conroy C. and M. Litvinoff (eds.) Greening of aid: sustainable livelihood practices. London: Earthscan. Pp $22-28$.

Narain, S., H.S. Panwar, M. Gadgil, V. Thapar and S. Singh. 2005. Joining the dots: the report of the Tiger Task Force. Delhi: The Ministry of Environment and Forests, Government of India.

Ostrom, E. 1990. Governing the commons: the evolution of institutions for collective action. Cambridge: Cambridge University Press.

Povinelli, E.A. 2002. The cunning of recognition: indigenous alterities and the making of Australian multiculturalism. Durham: Duke University Press.

Prabhu, P. 2005. The right to live with dignity. Seminar \#552.

Rajan, R.S. and C. A.M. Duncan. 2013. Ecologies of Hope: environment, technology and habitation - case studies from the intervenient middle. Journal of Political Ecology 20: 70-79.

Ranco, D. J. 2007. The ecological Indian and the politics of representation: critiquing the ecological Indian in the age of ecocide. In M.E. Harkin and D.R. Lewis (eds.) Native Americans and the environment: perspectives on the ecological Indian. Lincoln: University of Nebraska Press. 3 - 31.

Rangarajan, M. 1999. Fencing the forest. Delhi: Oxford University Press India.

Ramachandraiah, C. and R. Srinivasan. 2011. Special economic zones as new forms of corporate land grab: experiences from India. Development 54(1): 59 - 63. related

Ramnath, M. 2008. Surviving the Forest Rights Act: between scylla and charybdis. Economic and Political Weekly 43(9): 37-39.

Robbins, P., K. McSweeney, T. Waite and Rice, J. 2006. Even conservation rules are meant to be broken: implications for biodiversity. Environmental Management 37(2): $162-169$.

Robbins, P., K. McSweeney, A.K. Chhangani and J. Rice. 2009. Conservation as it is: illicit resource use in a wildlife reserve in India. Human Ecology 37(5): 559 - 575.

Rupp, S. 2008. Indigeneity: cosmopolitan images, local realities. Presented at the Yale University, April 25th.

Sahgal, B., L. Raman, B. Basu and S. Sharma. 2005. Citizens of the forest. Seminar \#552.

Sahu, G. 2008. Mining in the Niyamgiri Hills and tribal rights. Economic and Political Weekly 43(15): 19 22.

Sarin, M., N. M. Singh, N. Sundar and R. K. Bhogal. 2003. Devolution as a threat to decision-making in 
forestry? Findings from three states in India. ODI Working Papers, 197. London: Overseas Development Institute.

Sarin, M. 2007. Empowerment and disempowerment of forest women in Uttarakhand, India. In M. Rangarajan (ed.) Environmental issues in India. White Plains: Pearson Longman. Pp $483-506$.

Sharma, R. 2008. Decentralized forest governance in Central Himalayas: a re-evaluation of outcomes. Economic and Political Weekly 43(18): 54-61, 63.

Sivaramakrishnan, K. 1999. Modern forests: statemaking and environmental change in colonial Eastern India. Palo Alto: Stanford University Press.

Spiteri, A. and S. K. Nepalz. 2006. Incentive-based conservation programs in developing countries: a review of some key issues and suggestions for improvements. Environment Management 37(1): 14.

Springate-Baginski, O. and P.M. Blaikie (eds.). 2007. Forests, people and power: the political ecology of reform in South Asia. London: Earthscan.

The Economic Times. 2007. All women forest patrolling team in Periyar Tiger Reserve. [accessed on November 5, 2012] December 16. http://economictimes.indiatimes.com/womens-day/all-womenforest-patrolling-team-in-periyar-tiger-reserve/articleshow/2847368.cms.

UNDP. 2012. Winners of Government of India-UNDP Biodiversity Awards announced. Press Release. [accessed on July 2013] http://www.undp.org/content/undp/en/home/presscenter/pressreleases/2012/10/17/winners-ofgovernment-of-india-undp-biodiversity-awards-announced/.

Vaccaro, I., O. Beltran, and P-A. Paquet. 2013. Political ecology and conservation policies: some theoretical genealogies. Journal of Political Ecology 20: 255 - 272.

Wells, M.P. and T.O. McShane. 2004. Integrating protected area management with local needs and aspirations. Ambio 33(8): 513 - 519.

West, P. 2006. Conservation is our government now: the politics of ecology in Papua New Guinea. Durham: Duke University Press.

\begin{abstract}
In recent years, scholarly and civil society debates regarding tiger conservation in India have been sharply divided both in favor and against the efficacy of 'fortress' models of conservation that discourage subsistence-level access to resources by the local poor. Such debates have been further intensified since 2005 due to a drastic drop in the wild tiger population - presumably due to illegal poaching - and the passing of a Forest Rights Act that grants forest lands ownership rights to traditional forest-dependent communities. This article analyzes local community-forest collaboration in the Periyar Tiger Reserve in Kerala in Southern India. Periyar Tiger Reserve has been the only 'success story' out of the seven national parks where the India Eco-Development Project was implemented in 1997. The IEDP was funded by the World Bank, the Global Environmental Facility, and the Government of India to solicit the support of forest-adjacent communities in protecting wildlife habitats by offering them market-based livelihood opportunities. Information comes from ethnographic research conducted ten years after the EcoDevelopment Project was first implemented, and studies of the evolving nature of state-community relationships under the umbrella of a newly formed 'Government Organized Non-Governmental Organization' or GONGO. Theoretically, the article focuses the role of emotions and identity politics in shaping the worldviews of the participating community members, and not on the economic incentives of stakeholders. In doing so, I propose a more nuanced analysis of community-state relationships than is offered by polarized debates amongst conservationists and people's rights advocates in India and elsewhere. I illustrate the sense of ownership and regional pride shared by different social actors, in the context of the continuation of the fortress model of conservation.
\end{abstract}

Keywords: Biodiversity conservation, fortress conservation, eco-development, social fencing, identity politics, indigenous communities, tiger reserve, Kerala, India. 


\section{Résumé}

Au cours des dernières années, les débats concernant la conservation du tigre en Inde ont été très divisés sur l'efficacité des modèles «forteresse» de conservation qui découragent l'accès au niveau de subsistance à des ressources par la population locale. Ces débats ont été intensifiées depuis 2005, en raison d'une baisse drastique de la population de tigres sauvages - sans doute à cause du braconnage illégal - et l'adoption d'une loi sur les droits forestiers qui accorde les droits de propriété des terres forestières aux les communautés traditionnelles qui dépendent des forêts. Cet article analyse la collaboration communauté locale dans la Réserve naturelle de Periyar au Kerala en Inde du Sud. Periyar Tiger Reserve a été la seule «success story» des sept parcs nationaux où le projet d'éco-développement de l'Inde a été mis en œuvre en 1997. Le IEDP a été financé par la Banque Mondiale, les Fonds pour l'Environnement Mondial, et le gouvernement de l'Inde afin de solliciter le soutien des communautés vivant près des forêts pour la protection des habitats de la faune en leur offrant des moyens d'existence basés sur le marché. Ces informations proviennent d'une recherche ethnographique menée dix ans après le projet d'éco-développement a été mis en œuvre, et à partir d'études de l'évolution des relations entre l'État et la collectivité en vertu d'un nouveau «gouvernement organisé organisation non gouvernementale» ou GONGO. Théoriquement, l'article se concentre sur le rôle des émotions et les politiques identitaires dans l'élaboration de la vision du monde des membres de la communauté. Je propose une analyse plus nuancée des relations communauté-étatiques que celle offerte par les débats polarisés entre les écologistes et les défenseurs des droits humaines. J'illustre le sentiment d'appartenance et de fierté régionale partagée par les différents acteurs sociaux, dans le cadre de la poursuite du modèle forteresse de conservation.

Mots-clés: Conservation de la biodiversité, la conservation forteresse, l'éco-développement, l'escrime sociale, politique de l'identité, les communautés autochtones, réserve de tigres, Kerala, Inde.

\section{Resumen}

En lo últimos años, los debates tanto en la sociedad civil como en el mundo académico en torno a la conservación del tigre en India han estado radicalmente divididos entre quienes defienden y niegan la eficacia de los modelos de conservación en "fortaleza" que desestimulan el acceso a recursos a nivel de subsistencia de la población local pobre. Tales debates se han intensificado más aún tras 2005 debido a la drástica disminución de la población de tigres en libertad -presumiblemente debido a la caza furtiva- y a la aprobación del Acta de Derechos Forestales que garantiza el derecho a la propiedad de bosques a comunidades tradicionales dependientes de los bosques. Este artículo analiza la colaboración bosquecomunidad local en la reserva para tigres Periyar, en Kerala en el Sur de India. La reserva para tigres Periyar ha sido el único ejemplo exitoso de los siete parques nacionales donde el Proyecto de Desarrollo Ecológico de India (India Eco-Development Project, IDEP) se implementó en 1997. El IDEP recibió fondos del Banco Mundial, del Fondo para el Medioambiente Mundial y del Gobierno de India para pedir el apoyo de las comunidades adyacentes a los bosques con el fin de proteger hábitats naturales de vida salvaje, ofreciendo a estas comunidades oportunidades de subsistencia basadas en el mercado. La información se toma de investigación etnográfica llevada a cabo diez años después de la implementación del IDEP y de estudios de la naturaleza cambiante de las relaciones entre estado y comunidades que se encuentran bajo el paraguas de nuevas ONGOG (Organizaciones No Gubernamentales Organizadas por el Gobierno). Teóricamente, el artículo se centra en el rol de las emociones y de las políticas de identidad a la hora de formar la visión del mundo de los miembros de las comunidades participantes, y no en los incentivos económicos de las partes interesadas. Al hace esto, propongo un análisis más matizado de las relaciones entre estado y comunidades del que se ofrece por parte de los debates polarizados entre conservacionistas y defensores de los derechos de las poblaciones, tanto en India como en otras partes del mundo. Ilustro el sentimiento de propiedad y orgullo regional compartido por diferentes actores, en el contexto de la continuación del modelo de conservación de "fortaleza".

Palabras clave: Conservación de la biodiversidad, conservación fortaleza, eco-desarrollo, gestión social, políticas de identidad, comunidades indígenas, reserva de tigres, Kerala, India. 